\title{
Teachers' view about the current situation of e-learning practice in undergraduate medical education of Bangladesh
}

\author{
Talukder M.A.S., Talukder M.H.K., Pervin M.R., Talukder M.F.H., Tapu T.T.
}

\begin{abstract}
Background: E-learning or electronic learning is increasingly used as a complement to traditional classes in undergraduate medical education. E-Learning become more popular, because they allow saving time of teachers and students, reduce costs of teaching and learning materials and improve classroom as well as medical colleges' educational environment.
\end{abstract}

Objectives: This descriptive cross sectional survey was driven to explore teachers' view about the current situation of e-learning practice in undergraduate medical education of Bangladesh.

Methods: From all four phases, total 172 teachers of randomly selected eight medical colleges of Bangladesh were respondents of this study to seek information regarding the current situation of e-learning practice in undergraduate medical education, between the period of July 2018 to June 2019 with a pretested self-administered questionnaire.

Results: In this study 68 (39.5\%) were male and 104 (60.5\%) were female teachers. Fifty-two point three percent $(52.3 \%)$ teachers agreed that they strongly awared of e-learning, $87.8 \%$ teachers had personal computers/laptops, $99.4 \%$ teachers had personal smartphones, and $98.8 \%$ teachers had personal e-mail addresses. Fifty-three percent $(53 \%)$ teachers agreed that they have adequate knowledge and skill in information and communication technology (ICT). Forty-four percent (44\%) teachers disagreed that they were interact with students and $49.5 \%$ teachers agreed that they interacted with peer and colleague by using social media in their medical colleges.

Conclusion: Teachers are aware of e-learning and they practiced it in personal level without collaboration of the medical colleges. It is essential to provide e-learning facilities in medical colleges for improvement of undergraduate medical education.

Key Words: E-learning, Teachers' View, Undergraduate medical education, ICT.

1. Talukder M.A.S., Lecturer (Education Science), CME, Mohakhali, Dhaka, Bangladesh.

2. Talukder M.H.K., Professor (Curriculum Development \& Evaluation), CME, Mohakhali, Dhaka

3. Pervin M.R, Junior Consultant (Gynae and Obstetrics), RS (Gynae Oncology)

National Institute of Cancer Research \& Hospital (NICRH), Mohakhali, Dhaka, Bangladesh.

4. Talukder M.F.H., Assistant Professor (Conservative Dentistry), Sher-E-Bangla Medical College, Barisal

5. Tapu T.T., Lecturer (Education Science), CME, Mohakhali, Dhaka, Bangladesh.

Address of correspondence: Dr. Mohammad Abu Sayeed Talukder, Lecturer (Education Science), Centre for Medical Education (CME), Dhaka, Bangladesh

\section{Introduction}

Electronic-learning, or e-learning, describes the use of information technology or the internet for learning activities. The integration of e-learning into undergraduate, graduate, and continuing medical education is consistent with adult learning theory and presents a revolution in medical education ${ }^{1}$. Technology is a powerful tool for effective teaching and

Bangladesh Journal of Medical Education 2020; 11(1); Talukder et al., publisher and licensee Association for Medical Education. This is an Open Access article which permits unrestricted non-commercial use, provided the original work is properly cited. 
deeper learning. Incorporating technology into teaching and learning activities introduces new thinking about teaching effectively. It also increases opportunities to invent new learning experiences for students that will take us further beyond traditional classroom or lecture-based learning.

This study aims to introduce the teachers' view about the current situation of elearning practice in undergraduate medical education of Bangladesh. Experience shows that teachers and students are mostly in favor of adopting e-learning side-by-side with traditional learning, and the advantages far outweigh the likely discomfort associated with adoption of this new method.

Combination of face-to-face learning and elearning, are giving rise to didactic learning and are aiming to improve the quality and quantity of educational activities both in vertically and horizontally dimensions by using state-of-the-art technologies. In the horizontal dimension, the aim is to expand use of instruments to facilitate learning using a learning strategy in such a way to achieve the highest quality. In the vertical dimension, the aim is to carry out an indepth analysis of learning in order to better understand educational materials for optimized learning. The interactive nature of web- or internet-based e-learning, apart from facilitating access to the available learning strategies, over a wide range of time and location, enables researchers to benefit from different education management systems ${ }^{2}$.

E-learning is convenient as it can be done anywhere, at any time. The E-learning advancement approaches has become more improvised with the continuous developments of technologies; thus
Academic Staffs should always be efficiently consistent and steadily up-todate, incorporating these rapid developments into the web-based environment ${ }^{3}$. Palloff and Pratt $^{4}$ (2003) claimed that new delivery media and technology breakthroughs could affect teaching and learning environment; nevertheless the aims will not change, which is to satisfy the needs of the learners.

\section{Methodology}

This descriptive cross sectional study was conducted among 172 medical teachers from eight medical colleges of Bangladesh out of which two government medical colleges (Dhaka Medical College, Dhaka and Shaheed Suhrawardy Medical College, Dhaka) and two non-government medical colleges (Delta Medical College, Dhaka and Bangladesh Medical College, Dhaka) located in Dhaka, and another two government medical colleges (Rajshahi Medical College, Rajshahi and Shekh Hasina Medical College, Tangail) and two non-government medical colleges (Islami Bank Medical College, Rajshahi and Chattogram Maa O Shishu Hospital \& Medical College, Chattogram) were located outside Dhaka, during July 2018 to June 2019 using a pre-tested self-administered semi-structured questionnaire. The questionnaire was distributed among the teachers and was collected immediately after completion. Teachers' participation was voluntary. Confidentiality and anonymity were strictly maintained. All ethical issues were considered and necessary permission was taken from ethical committee of the Centre for Medical Education (CME) and respected medical colleges before the data collection. Collected data were verified, compiled, tabulated and analyzed.

Bangladesh Journal of Medical Education 2020; 11(1); Talukder et al., publisher and licensee Association for Medical Education. This is an Open Access article which permits unrestricted non-commercial use, provided the original work is properly cited. 


\section{Original Article}

\section{Results}

Out of the 172 teachers of the survey, maximum $47.1 \%$ teachers were lecturers, $18 \%$ were Assistant Professors, $15.1 \%$ were Associate Professors, $8.1 \%$ were Assistant registrars, $6.4 \%$ were Professors, $2.3 \%$ were Junior consultant, $2.3 \%$ were Registrars and
$0.6 \%$ were Senior consultant (Figure 1). Out of them $60.5 \%$ were female and $39.5 \%$ were male, $87.8 \%$ teachers had personal computers (PC)/laptops, $99.4 \%$ teachers had personal smartphones \& $98.8 \%$ teachers had personal email addresses.

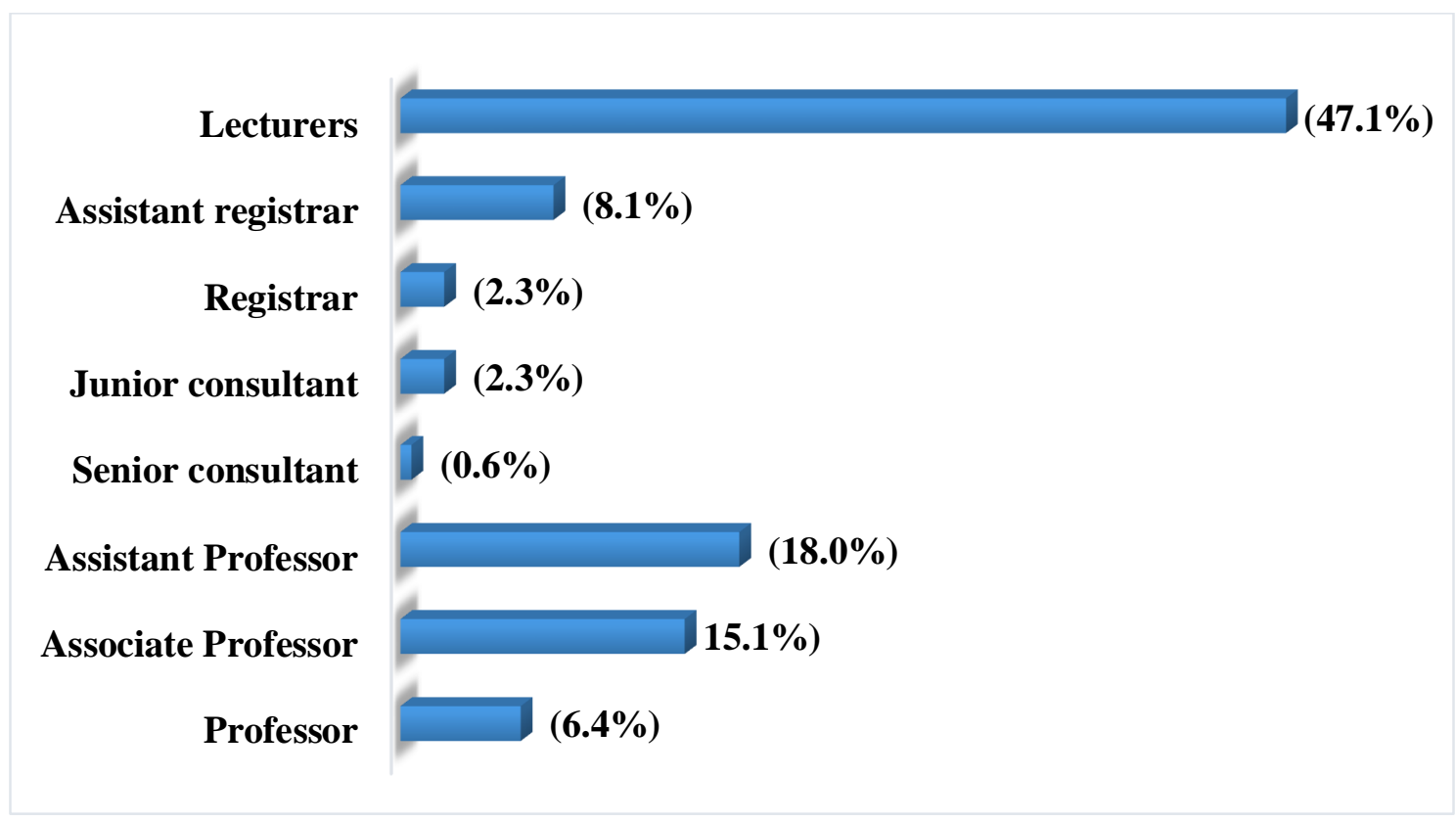

Figure 1: Distribution of the medical teachers by their designation $(n=172)$

Table 1 shows that out of 172 teachers, $53 \%$ teachers agreed that they had adequate knowledge and skill in information and communication technology (ICT), 47.7\% teachers agreed that they had installed all necessary software and antivirus which helped to secure their PCs/laptops completely, 38.4\% teachers strongly agreed \& $37.7 \%$ teachers agreed that they were using password which helped to secure their PCs/laptops completely.

Table 1 Distribution of the medical teachers regarding general views by them about the use of personal computer (PC)/laptop

\begin{tabular}{|l|c|c|c|c|c|}
\hline \multirow{2}{*}{$\begin{array}{l}\text { Statements in relation to the use of } \\
\text { PC/laptop of teachers }\end{array}$} & \multicolumn{5}{|c|}{ Level of agreement } \\
\cline { 2 - 6 } & $\begin{array}{c}\text { SDA } \\
\text { f (\%) }\end{array}$ & $\begin{array}{c}\text { DA } \\
\text { f (\%) }\end{array}$ & $\begin{array}{c}\text { NAND } \\
\text { f (\%) }\end{array}$ & $\begin{array}{c}\text { A } \\
\text { f (\%) }\end{array}$ & $\begin{array}{c}\text { SA } \\
\text { f (\%) }\end{array}$ \\
\hline Adequate knowledge and skill in ICT. & 2 & 16 & 34 & 80 & 19 \\
& $(1.3)$ & $(10.6)$ & $(22.5)$ & $(53.0)$ & $(12.6)$ \\
\hline Installed all necessary software in their & 5 & 25 & 19 & 72 & 30 \\
PC/laptop. & $(3.3)$ & $(16.6)$ & $(12.6)$ & $(47.7)$ & $(19.9)$ \\
\hline
\end{tabular}

Bangladesh Journal of Medical Education 2020; 11(1); Talukder et al., publisher and licensee Association for Medical Education. This is an Open Access article which permits unrestricted non-commercial use, provided the original work is properly cited. 
Original Article

\begin{tabular}{|l|c|c|c|c|c|}
\hline $\begin{array}{l}\text { Installed an antivirus which helped to secure } \\
\text { their PC/laptop completely. }\end{array}$ & $\begin{array}{c}7 \\
(4.6)\end{array}$ & $\begin{array}{c}13 \\
(8.6)\end{array}$ & $\begin{array}{c}8 \\
(5.3)\end{array}$ & $\begin{array}{c}72 \\
(47.7)\end{array}$ & $\begin{array}{c}51 \\
(33.8)\end{array}$ \\
\hline $\begin{array}{l}\text { Were using password which helped to secure } \\
\text { their PC/laptop completely. }\end{array}$ & 7 & 20 & 9 & 57 & 58 \\
& $(4.6)$ & $(13.2)$ & $(6.0)$ & $(37.7)$ & $(38.4)$ \\
\hline
\end{tabular}

Table 2 shows that out of 172 teachers, $52.3 \%$ teachers agreed that they were strongly aware of e-learning, $42.4 \%$ teachers disagreed that most of the time they practiced e-learning in addition to lecture classes by providing their lectures and handouts in social media/e-mail/ youtube, $45.3 \%$ teachers disagreed that most of the time they practiced e-learning in addition to tutorial, bedside, demonstration, practical classes by providing their lectures in social media/email/youtube. To informed the students about their class on its' cancelation or delayed, $36.6 \%$ teachers disagreed that they were using social media or e-mail.

Table 2 Distribution of the medical teachers regarding the general views by them about the present status of e-learning in medical colleges

\begin{tabular}{|c|c|c|c|c|c|}
\hline \multirow{2}{*}{$\begin{array}{l}\text { Statements in relation to the present } \\
\text { status of e-learning in medical colleges } \\
\text { by the teachers }\end{array}$} & \multicolumn{5}{|c|}{ Level of agreement } \\
\hline & $\begin{array}{l}\text { SDA } \\
\text { f }(\%)\end{array}$ & $\begin{array}{c}\text { DA } \\
\mathbf{f}(\%)\end{array}$ & $\begin{array}{l}\text { NAND } \\
\text { f }(\%)\end{array}$ & $\begin{array}{c}\mathrm{A} \\
\mathbf{f}(\%)\end{array}$ & $\begin{array}{c}\text { SA } \\
\mathbf{f}(\%)\end{array}$ \\
\hline $\begin{array}{l}\text { Teachers were strongly aware of e- } \\
\text { learning. }\end{array}$ & $\begin{array}{c}4 \\
(2.3)\end{array}$ & $\begin{array}{c}35 \\
(20.3)\end{array}$ & $\begin{array}{c}22 \\
(12.8)\end{array}$ & $\begin{array}{c}90 \\
(52.3)\end{array}$ & $\begin{array}{c}21 \\
(12.2)\end{array}$ \\
\hline $\begin{array}{l}\text { Most of the time in addition they practiced } \\
\text { e-learning in lecture class }\end{array}$ & $\begin{array}{c}23 \\
(13.4)\end{array}$ & $\begin{array}{c}73 \\
(42.4) \\
\end{array}$ & $\begin{array}{c}27 \\
(15.7)\end{array}$ & $\begin{array}{c}42 \\
(24.4) \\
\end{array}$ & $7(4.1)$ \\
\hline $\begin{array}{l}\text { Most of the time in addition they practiced } \\
\text { e-learning in tutorial class }\end{array}$ & $\begin{array}{c}27 \\
(15.7)\end{array}$ & $\begin{array}{c}78 \\
(45.3)\end{array}$ & $\begin{array}{c}29 \\
(16.9)\end{array}$ & $\begin{array}{c}37 \\
(21.5)\end{array}$ & $1(0.6)$ \\
\hline $\begin{array}{l}\text { Most of the time in addition they practiced } \\
\text { e-learning in bedside/ demonstration/ } \\
\text { practical class }\end{array}$ & $\begin{array}{c}28 \\
(16.3)\end{array}$ & $\begin{array}{c}78 \\
(45.3)\end{array}$ & $\begin{array}{c}30 \\
(17.4)\end{array}$ & $\begin{array}{c}32 \\
(18.6)\end{array}$ & $4(2.3)$ \\
\hline $\begin{array}{l}\text { Teachers were always informed to the } \\
\text { students about their class by using social } \\
\text { media or e-mail. }\end{array}$ & $\begin{array}{c}21 \\
(12.2)\end{array}$ & $\begin{array}{c}63 \\
(36.6)\end{array}$ & $\begin{array}{c}42 \\
(24.4)\end{array}$ & $\begin{array}{c}34 \\
(19.8)\end{array}$ & $\begin{array}{c}12 \\
(7.0)\end{array}$ \\
\hline
\end{tabular}

\section{Discussion}

Information Technology (IT) and communications are pervasive in all social aspects, including the educational area, due to the need of getting information from beyond geographic borders. Such technologies provide opportunities for higher educational institution to enhance the learning environment of the students as well as the management and administration of program and module delivery and support ${ }^{5}$.

In this study 68 (39.5\%) were male teachers and $104(60.5 \%)$ were female teachers (Figure 2). From this data we see the general trend of medical education in Bangladesh. But in another study in Melaka Manipal Medical College, Malaysia showed that there were total $41(77.4 \%)$ male faculties and $12(22.6 \%)$ female faculties among total participants ${ }^{6}$. This is a positive development reflecting the women empowerment in Bangladesh despite many obstacles.

This study showed that 52.3\% teachers agreed and $12.3 \%$ teachers strongly agreed about awareness of e-learning. Almost similar perception found in a study in Melaka Manipal Medical College, Malaysia showed that about Bangladesh Journal of Medical Education 2020; 11(1); Talukder et al., publisher and licensee Association for Medical Education. This is an Open Access article which permits unrestricted non-commercial use, provided the original work is properly cited. 
$65.4 \%$ of faculty held positive opinion towards e-learning ${ }^{6}$.

About $65.6 \%$ teacher stated that they had adequate knowledge and skill in ICT, about $67.6 \%$ teachers stated that they installed all necessary software in their computer and laptop. In another study in Melaka Manipal Medical College, Malaysia showed that most of the faculty had adequate knowledge and skills on computer and software ${ }^{6}$.

About $55.8 \%, 70.0 \%$ and $61.6 \%$ teachers did not practice e-learning in lecture class, tutorial class and bedside/ demonstration/ practical class respectively. In an another study faculty of Melaka Manipal Medical College, Malaysia stated that $75 \%$ teachers agreed towards adoption of e-learning in blended Problem based learning that includes both online and traditional approach, integrating the clinical skills and bed side clinical teaching, but about $15.7 \%$ were uncertain and $8.8 \%$ revealed negative responses about e-learning ${ }^{6}$.

\section{References}

1. Khaled Zehry, Neel Halder, Louise Theodosiou (2011), E-Learning in medical education in the United Kingdom, Procedia Social and Behavioral Sciences, Published by Elsevier Ltd, 15, 3163-3167

2. Ghasemi N, Falsafi P, Aminabadi NA, Negahdari R, Bahramian A, Khodadoust K and Khiyavi RK 2016, E-Learning in Medical Sciences Education: A, Comprehensive Literature Review, Paripex - Indian Journal Of Research, Volume : 5, Issue : 1, ISSN - 2250-1991, 107-109.

3. Salehi H, Shojaee M and Sattar S 2015, Using E-Learning and ICT Courses in Educational Environment: A Review, English Language Teaching; Vol. 8, No. 1; 2015, ISSN 1916-4742 E-ISSN 19164750, Published by Canadian Center of Science and Education.

\section{Conclusion}

The use of computer and internet is rapidly becoming a key component of medical education in many parts of the world. The results of this study indicate that most of the medical teachers of Bangladesh had access and orientation to computer and internet. Most of the accesses and uses were the result of their individual initiative. Need to motivate the policy makers, authorities, teachers and students in the medical colleges to implement and practice e-learning, provision of structured computer and Information Technology (IT) training and its inclusion into the MBBS curriculum, setting up of IT lab, e- library, WiFi facility etc. would equip them with the skills they need up-to-date knowledge and practice in real life in future, which are essential to improve the quality of medical care.

4. Palloff, R.M. and Pratt, K. (2003), The Virtual Student: A Profile and Guide to Working with Online Learners, The JosseyBass Higher and Adult Education Series, John Wiley \& Sons, Hoboken, NJ.

5. Mercado CA (2008), Readiness Assessment Tool for An eLearning Environment Implementation, Fifth International Conference on e-learning for Knowledge-Based Society, Bangkok, Thailand.

6. Bhardwaj A, Nagandla K, Swe KMM, Abas ABL (2015), Academic Staff Perspectives Towards Adoption of ELearning At Melaka Manipal Medical College: Has E-Learning Redefined Our Teaching Model? Kathmandu Univ Med $\mathrm{J} ; 49(1): 12-8$.

Bangladesh Journal of Medical Education 2020; 11(1); Talukder et al., publisher and licensee Association for Medical Education. This is an Open Access article which permits unrestricted non-commercial use, provided the original work is properly cited. 